\title{
Isotope encephalography in the management of acute herpesvirus encephalitis
}

\author{
A. S. Bligh, C. M. Weaver, AND C. E. C. WElls \\ From the Departments of Radiology, Child Health, and Neurology, \\ Cardiff Royal Infirmary, Cardiff, Wales
}

SUMMARY Two patients with Herpesvirus hominis (herpes simplex) encephalitis were investigated by serial isotope encephalograms using technetium-99m pertechnetate. In the first case the diagnosis was made by brain biopsy, and by successful tissue culture, and was confirmed by a significant rise in antibody titre, but in the second the laboratory evidence was exclusively serological. Necrotizing encephalitis was presumed in both cases because the illness was grave and focal signs developed in conjunction with radiological and electroencephalographic evidence of circumscribed lesions of the hemisphere. The emergence of new lesions in the brain scan at a time of clinical remission was found to be a warning of impending relapse. Such lesions had to be distinguished from areas of increasing uptake of isotope due only to local change in vascular permeability. Decay of EEG activity together with clinical signs of focal abnormality over an area of isotope concentration indicated a necrotizing lesion. Cytosine arabinoside (cytarabine), an alternative to idoxuridine as an antiviral drug, was used in both cases. A third patient, suspected in life of having a degenerative encephalopathy, was found at necropsy to have necrotizing encephalitis. Herpes infection though probable was not confirmed. The most severe lesions were in the frontal and temporal lobes, which had shown increased uptake of technetium in the encephalogram performed six weeks before her death.

For 30 years, since Herpes simplex was first isolated from the brain of a dying child (Smith, Lennette, and Reames, 1941), the virus has been known for its sporadic but virulent neurotropism. Occasionally giving rise to a fulminating infection of the newborn (Zuelzer and Stulberg, 1952; Nahmias, Dowdle, Josey, Naib, Painter, and Luce, 1969) and to a more benign meningoencephalitis at all ages (Afzelius-Alm, 1951; Adair, Gould, and Smadel, 1953; Meyer, Johnson, Crawford, Dascomb, and Rogers, 1960; Ross and Stevenson, 1961; Leider, Magoffin, Lennette, and Leonards, 1965; Olson, Buescher, Artenstein, and Parkman, 1967), it is also the usual cause of acute necrotizing encephalitis (Haymaker, 1949; van Bogaert, Radermecker, and Devos, 1955; Krücke, 1957; Jellinger, Poetsch, and Seitelberger, 1964), which may mimic cerebral tumour, abscess, subdural empyema, or tuberculous meningitis (Adams and Jennett, 1967). A few cases have been attributed to other infections, such as lymphocytic choriomeningitis (Scheid, Jochheim, and Stammler, 1955) and psittacosis (Duckett, Kelly, and Grant, 1963), or to an enterovirus (Heathfield, Pilsworth, Wall, and Corsellis, 1967).

The natural history of necrotizing encephalitis due to Herpesvirus hominis (Haymaker, Smith, van Bogaert, and de Chenar, 1958; Brihaye, 1959; Carmon, Behar, and Beller, 1965; Bergouignan, Julien, Vital, and Duvert, 1968; Jacoby, Blennerhassett, and Richardson, 1971) is divisible into stages. An influenza-like prodrome, when the mucocutaneous eruption may appear (Hunt and Comer, 1955), is shortly followed by symptoms of cerebral invasion-high fever, stupor, meningeal irritation, epilepsy, and hemiplegia. Sometimes the onset is indolent (Drachman and Adams, 1962; Blackwood, Dudgeon, Newns, and Phillips, 1966). Signs of an expanding mass (Wolf and Cowen, 1950; Bennett, ZuRhein, and Roberts, 1962; Pierce, Portnoy, Leeds, Morrison, and Wehrle, 1964), commonly 
frontal or temporal, often lead to surgical intervention (Adams and Jennett, 1967). Death occurs in the second or third week (Miller, Hesser, and Tompkins, 1966; Olson et al., 1967). Of those few who survive a month or more the majority face a prospect of permanent mental and physical handicap punctuated by frequent fits, as full recovery is exceptional (Meyer et al., 1960; Leider et al., 1965; Miller et al., 1966; Olson et al., 1967; Bergouignan et al., 1968; Miller and Ross, 1968).

The infection is diagnosed by brain biopsy (Dodge and Cure, 1956; Booth, Okazaki, and Gaulin, 1961 ; MacCallum, Potter, and Edwards, 1964) and confirmed by a fourfold or greater rise in serum antibody titre (Ross and Stevenson, 1961). A single titre $>512$ is held to be diagnostic of active infection (Miller and Ross, 1968). Electron microscopy is a quick and reliable method of finding virus particles (Ryden, Moses, Ganote, and Beaver, 1965; Itabashi, Bass, and McCulloch, 1966; Delmas-Marsalet, Bergouignan, Castaing, du Pasquier, and Vital, 1968) but, being non-specific, must be supported by biological and serological tests (Harland, Adams, and McSeveney, 1967; Johnson, Olson, and Buescher, 1968).

Herpetic invasion of the brain-blood-borne, by local spread along olfactory and trigeminal nerves (Johnson, 1964), or from a latent source of infection (Leider et al., 1965; Rawls, Dyck, Klass, Green, and Herrmann, 1966) - is widespread but irregular. Areas of massive necrosis distort the frontal and temporal lobes, focal haemorrhages in the cortex often disrupting the subjacent white matter (Haymaker et al., 1958; Jellinger et al., 1964). Clusters of intranuclear (Cowdry, 1934) and cytoplasmic (Haymaker, 1949) inclusions establish the viral aetiology (Krücke, 1957). Most infections of older children and adults are with type I Herpesvirus hominis (Dowdle, Nahmias, Harwell, and Pauls, 1967) whereas type II virus is the usual cause of neonatal illness (Nahmias et al., 1969).

The simplicity of isotope encephalography makes it particularly suitable for children (Maynard and Kelsey, 1969) and for very ill patients. With technetium-99m pertechnetate the dose of radiation is small and less than that of a contrast angiogram (Harper, Beck, Charleston, and Lathrop, 1964; Smith, 1965; Kuhl, Pitts, and
Tucker, 1966). Serial scanning is safe, does not need an anaesthetic, and carries none of the risks of intra-arterial thrombosis. A reliable monitor of cerebral infarction (Glasgow, Currier, Goodrich, and Tutor, 1965; Molinari, Pircher, and Heyman, 1967; Usher and Quinn, 1969; Marshall and Popham, 1970), it has proved equally useful in localizing the infarct-like lesions of necrotizing encephalitis and in gauging their severity (Sweet, Mealey, Aronow, and Brownell, 1961; Drachman and Adams, 1962; Castleman, 1964; Breeden, Hall, and Tyler, 1966; Balfour, Loken, and Blaw, 1967; Page, Tyler, and Shillito, 1967; McKee, Hudson, Kimura, and McCormick, 1968; Davis and Potchen, 1970; Halpern, Smith, and Ficken, 1970; Mishkin, 1970; Nolan, Carruthers, and Lerner, 1970; Clizer and Ioannides, 1971; Jacoby et al., 1971; Meyer, Bauer, Rivera-Olmos, Nolan, and Lerner, 1971; Radcliffe, Guinto, Adcock, and Krigman, 1971; Rappel, Dubois-Dalcq, Sprecher, Thiry, Lowenthal, Pelc, and Thys, 1971).

\section{CASE REPORTS}

Two cases are reported below of presumed necrotizing encephalitis due to infection with Herpesvirus hominis. In the first the virus wase isolated by brain biopsy and the infection was confirmed by a diagnostic rise in the level of serum antibody. The second case also showed a significant rise in antibody titre but brain biopsy was unsuccessful. Serial scanning with technetium-99m pertechnetate was correlated with the clinical course of the illness, with angiographic and electroencephalographic findings, and with the effect of steroids and cytotoxic drugs.

\section{CASE 1}

A 6 year old boy was taken ill on 10 July 1970 with headache, fever, and sore throat. His family doctor prescribed ampicillin. During the evening of 12 July he had several convulsions lasting a quarter of an hour before he was admitted to a local hospital. His previous health had been excellent.

On admission he was stuporous with temperature $40^{\circ} \mathrm{C}$, pulse 160 per minute, and blood pressure $120 / 80 \mathrm{~mm} \mathrm{Hg}$. No rash, ulcers, nor petechiae were seen. Heart, lungs, abdomen, and urine were normal. Slight neck stiffness was found. Pupils and fundi were normal, but the tone of all the limbs was increased, 
tendon reflexes were absent, and both plantar responses were flexor.

A clear fluid was obtained at lumbar puncture, with 115 WBC (92\% lymphocytes) and $12 \mathrm{RBC} /$ c.mm, $42 \mathrm{mg}$ protein, and $90 \mathrm{mg}$ glucose $/ 100 \mathrm{ml}$. Bacterial culture of the spinal fluid and of blood, throat swab, and urine, and virus culture of faeces were all negative. Cultures of spinal fluid for acidfast bacteria were also negative. Other investigations included a radiograph of the chest which was normal and a blood count with haemoglobin $13.5 \mathrm{~g} / 100 \mathrm{ml}$. WBC $14,000 /$ c.mm $(91 \%$ polymorphs, $9 \%$ lymphocytes), and sedimentation rate $10 \mathrm{~mm}$ in $1 \mathrm{hr}$. Serum electrolytes were normal, blood sugar $90 \mathrm{mg}$, and urea $20 \mathrm{mg} / 100 \mathrm{ml}$. Mantoux test was negative at $1: 1,000$.

Hydrocortisone was given intravenously, together with ampicillin, chloramphenicol, and sulphadiazine in doses adjusted for body weight $(25 \mathrm{~kg})$. Adrenocorticotrophin was begun on 17 July.

He remained unresponsive with an irregular fever swinging to $39.5^{\circ} \mathrm{C}$ until the evening of $17 \mathrm{July}$ when he had two generalized convulsions in quick succession. A second lumbar puncture on the previous day had again shown a clear fluid with no increase of WBC but containing $250 \mathrm{RBC} / \mathrm{c} . \mathrm{mm}, 35 \mathrm{mg}$ protein, and $80 \mathrm{mg}$ glucose $/ 100 \mathrm{ml}$. An electroencephalogram (EEG) on the morning of 17 July showed generalized slow activity with a periodic delta focus in the left posterior temporal region (Fig. 1).
On 18 July he was transferred to Cardiff Royal Infirmary. He was comatose with neck rigidity, trismus, and positive Kernig sign. Persistent twitching of the right hand (epilepsia partialis continua) was seen. Pupils were dilated but reacted to light. The fundi were normal and corneal reflexes present. Rigidity of all four limbs was more marked on the right. Tendon reflexes were absent, the plantar responses both extensor. The skin and mucous membranes were normal. The liver edge was just palpable but no enlargement of spleen nor of lymph nodes was found. Intravenous diazepam controlled the focal epilepsy.

Left carotid angiogram (Fig. 2) on 20 July showed elevation of the middle cerebral vessels with stretching of the anterior temporal branch. The midline vessels were displaced to the right (Fig. 3). Cerebral scan on 21 July, one hour after intravenous injection of $2.5 \mathrm{mc}$ technetium-99m pertechnetate, showed an area of increased uptake in the left posterior temporal region (Fig. 4) extending into the parietal area. On 22 July virus particles with the characteristics of Herpesvirus hominis were identified by electron microscopy in a biopsy specimen and the virus was later grown in tissue culture. By 28 July the complement fixation titre for $H$. hominis which had been $<1: 8$ on 15 July had risen to $1: 1024$.

The therapeutic regime of steroids, adrenocorticotrophin and antibiotics was continued until 23 July. On that day cytosine arabinoside (cytarabine),

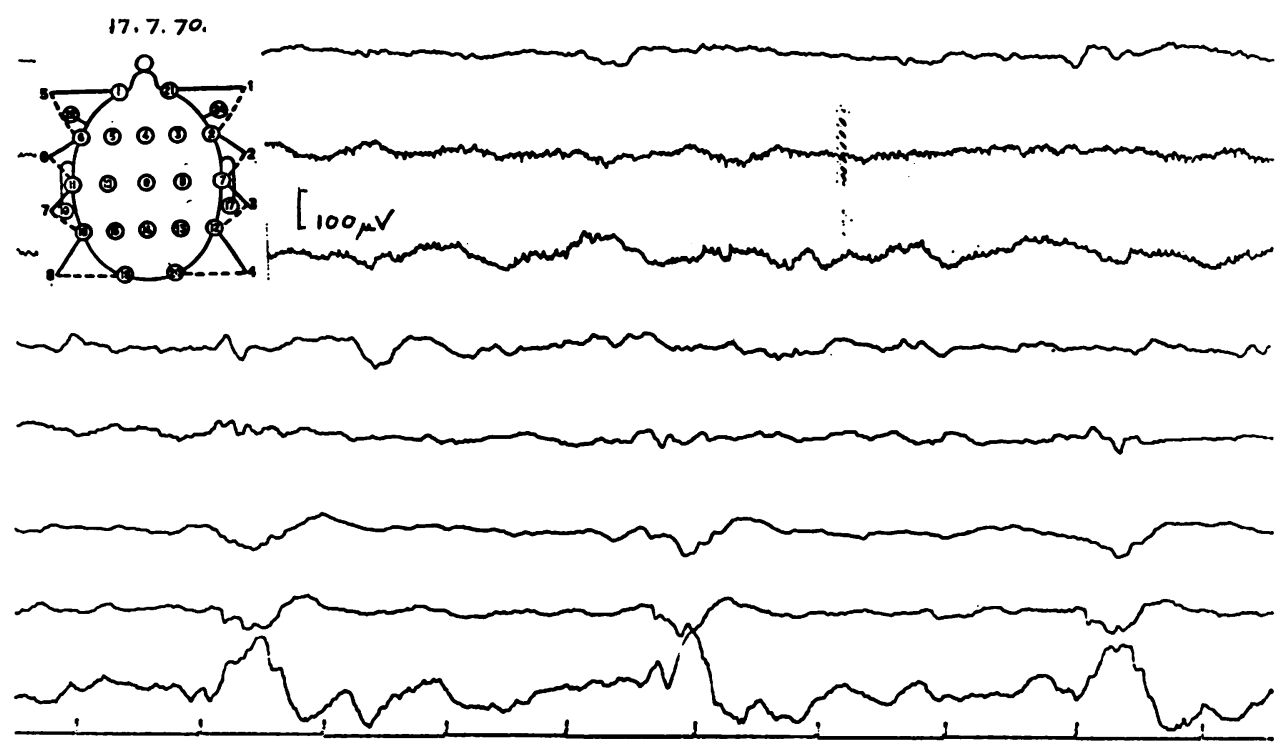

FIG. 1. Case 1. Electroencephalogram (17 July 1970). Generalized slow waves with periodic delta focus in left posterior temporal region. 




FIG. 2. Case 1. Left carotid angiogram (20 July 1970). Lateral view showing elevation of middle cerebral vessels with stretching of anterior temporal branch.



FIG. 3. Case 1. Left carotid angiogram (20 July 1970). Anterior view showing displacement of midline vessels to right.

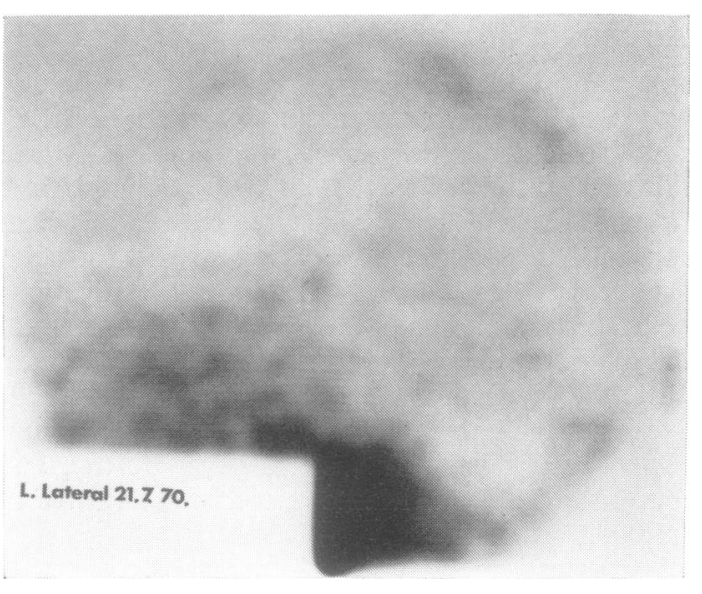

FIG. 4. Case 1. Isotope encephalogram (21 July 1970). Left lateral scan showing area of increased uptake in posterior temporal region.

$0.3 \mathrm{mg} / \mathrm{kg} /$ day (total $7.5 \mathrm{mg}$ ), was begun as an intravenous infusion, the dose being raised to $0.6 \mathrm{mg} / \mathrm{kg} /$ day (total $15 \mathrm{mg}$ ) from $24 \mathrm{July}$ and to $1.8 \mathrm{mg} / \mathrm{kg} / \mathrm{day}$ (total $45 \mathrm{mg}$ ) from $25 \mathrm{July}$. Penicillin and anti $\frac{0}{\mathbb{0}}$ \& convulsants were continued.

On 25 July he was lightly stuporous, sometimes opening his eyes and moving his limbs on command 0 He could now be fed by spoon. When his arms were raised passively they developed a coarse tremor and showed considerable rigidity. His improvement was maintained over the next 10 days and he became



FIG. 5. Case 1. Isotope encephalogram (4 August 1970). Right lateral scan showing multiple areas of abnormal uptake in frontal and parietal regions. 


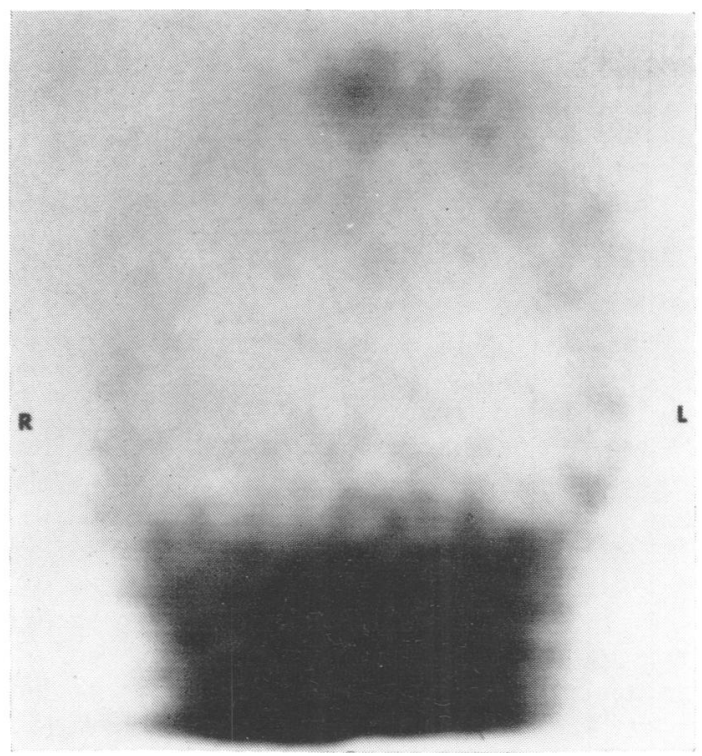

FIG. 6. Case 1. Isotope encephalogram (4 August 1970). Anterior scan showing left-sided lesion which follows the curve of the vault. Faint area of abnormal uptake on the right.

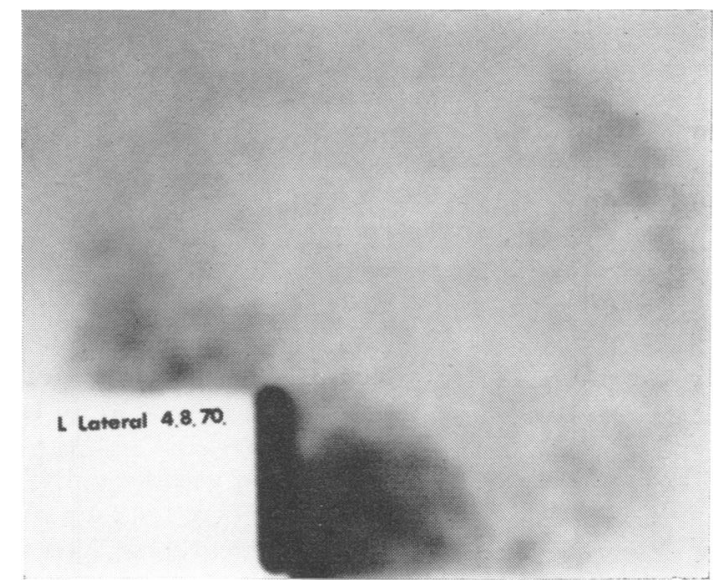

FIG. 7. Case 1. Isotope encephalogram (4 August 1970). Left lateral scan showing migration of posterior temporal lesion to the periphery. Compare with Fig. 4.

afebrile. Cytarabine was discontinued on 2 August but was restarted on 5 August when the third lumbar puncture showed $14 \mathrm{WBC}$ and $41 \mathrm{RBC} / \mathrm{c} . \mathrm{mm}, 88 \mathrm{mg}$ protein, and $58 \mathrm{mg}$ glucose $/ 100 \mathrm{ml}$. The fluid was again clear and bacterial culture sterile.

The second brain scan on 4 August showed new areas of abnormal uptake in the right hemisphere (Fig. 5) and apparent migration of the left posterior
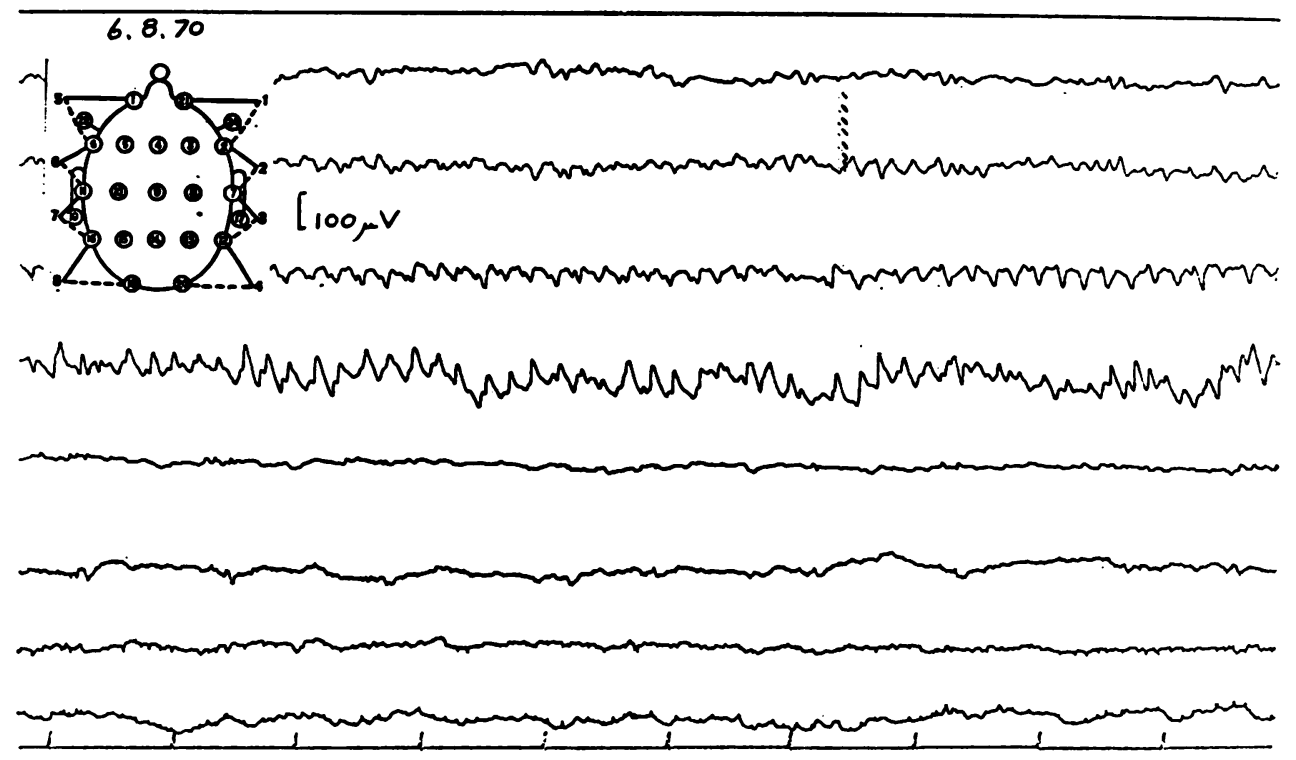

FIG. 8. Case 1. Electroencephalogram (6 August 1970). Right parietal ictal discharge of sharp waves at 5-6 Hz. 
temporal lesion to the periphery (Figs 6 and 7). Leftsided twitching, partially suppressed by diazepam and phenytoin, began on 6 August, the EEG showing a right parietal ictal discharge (Fig. 8). At this stage he became less accessible, tremor increased and fever returned, and on 14 August he had several generalized fits. The EEG now showed flattening of the record in leads from the right hemisphere against a background of generalized slow activity. In a third scan on 21 August the left-sided lesion had increased in size and in intensity of uptake (Figs 9 and 10), although the EEG no longer showed a focal abnormality in this area.

Lumbar puncture on 22 August was normal. The fluid was clear with no increase of cells, $48 \mathrm{mg}$ protein, and $65 \mathrm{mg}$ glucose $/ 100 \mathrm{ml}$. Intravenous idoxuridine was started on 24 August and five daily doses of $100 \mathrm{mg} / \mathrm{kg}$ (daily total $2.5 \mathrm{~g}$ ) were given. No improvement was seen. He remained stuporous with frequent shuddering tremors, opening his eyes on painful stimulation only and continuously grimacing. Low remittent fever persisted. The optic discs remained flat, the right plantar response became flexor but the left was still extensor. Myoclonic jerks occurred in bursts which were independent of EEG changes. Reversal of sleep rhythm developed shortly before he returned to his local hospital on 3 September.

Throughout the period of cytarabine and idoxuridine therapy blood counts were performed regularly. During the first week of August he became anaemic and by 9 August the haemoglobin had fallen to $9.6 \mathrm{~g} / 100 \mathrm{ml}$, with RBC 3.02 millions and WBC $3,100 /$ c.mm $(59 \%$ polymorphs, $39 \%$ lymphocytes, $1 \%$ monocytes, $1 \%$ eosinophils) and platelets 240,000 per c.mm. One unit of blood, group A $\mathrm{Rh}(\mathrm{D})+$, was transfused on 12 August. Thereafter repeated counts were normal.

During the next three months consciousness gradually returned and the frequency of his epileptic fits diminished. By January 1971 he was able to sit unaided, to walk between bars, and to stand by supporting himself on the furniture. Ten months later he had not regained useful speech, could not feed himself, and had no proper control of sphincters. Major and minor epileptic fits continued to occur several times a day.

\section{CASE 2}

A 9 year old boy had been listless for a fortnight when he started to complain of headache and abdominal pain. His general practitioner found that he was febrile and prescribed paracetamol. Within 48 hours he had become drowsy and ampicillin was given. Three days later, on 11 October 1971, he was admitted to hospital.

On transfer to Cardiff Royal Infirmary on the evening of the same day he was conscious but inattentive, lay curled on his side and resented examination. His temperature was $38^{\circ} \mathrm{C}$ and pulse rate 82 per minute. Neck stiffness and Kernig's sign were found. He had a mild left hemiparesis, with sluggish reflexes and flexor plantar responses. Soon after his admission he had three small fits which were followed by deepening stupor and dense left hemiplegia with left extensor plantar response.

The spinal fluid was clear with resting pressure $180 \mathrm{~mm}$. It contained $266 \mathrm{RBC}$ and $154 \mathrm{WBC}$ (mostly lymphocytes)/c.mm, $65 \mathrm{mg}$ protein, and $70 \mathrm{mg}$ glucose $/ 100 \mathrm{ml}$. Bacterial culture was sterile and no organisms were seen on the Ziehl-Neelsen film. The peripheral blood showed a leucocytosis of $15,600 /$ c.mm. The Mantoux test was negative at $1: 1,000$.

In the first EEG on 11 October diffuse slow activity at delta and sub-delta frequencies was seen, with greater amplitude in leads from the right hemisphere. There was no focus. Further records on 15 October and 20 October were similar. The first brain scan with technetium-99m pertechnetate on 12 October indicated a right occipitotemporal lesion which had become more pronounced in the second scan (Figs or 11 and 12) on 15 October. Tissue from a right fronta\$ of brain biopsy on 12 October was unsuitable fog laboratory examination and was not processed Complement fixation tests for Herpes simplex showed $\overrightarrow{0}$ a rise in titre from 1:16 on 11 October to $1: 512$ on 22 October. Culture of faeces for enteroviruses wag negative.

Viral encephalitis was diagnosed on the clinica $\overrightarrow{0}$ EEG, and laboratory findings and, in view of the ab normal scan, herpes simplex was suspected. The red cell pleocytosis of the spinal fluid, which was a feature of the first case, was thought to be additional evidence in favour of this diagnosis (Miller et al., 1966). Although proof of herpesvirus infection was not forthcoming, the rising titre of serum antibody. was highly significant (Ross and Stevenson, 1961; Miller and Ross, 1968).

Cytosine arabinoside (cytarabine) was given daily as an intravenous infusion from 12 to 18 October in a dose of $3.5 \mathrm{mg} / \mathrm{kg} /$ day. The total dose was $700 \mathrm{mg}$ (weight $28.25 \mathrm{~kg}$ ). In addition dexamethasone, $8 \mathrm{mg}$ daily in divided doses, was given from 12 to 21 October, was then reduced and stopped on 23 October. Phenytoin was given throughout his stay in hospital.

By the evening of 13 October, 24 hours after 은 chemotherapy and steroids had begun, he was con- $D$ scious and afebrile but the left hemiplegia persisted. 을 On regaining consciousness he was found to have a left homonymous hemianopia. He spoke to his o mother on 16 October and took a few steps with sup- 
$\mathbf{L}$

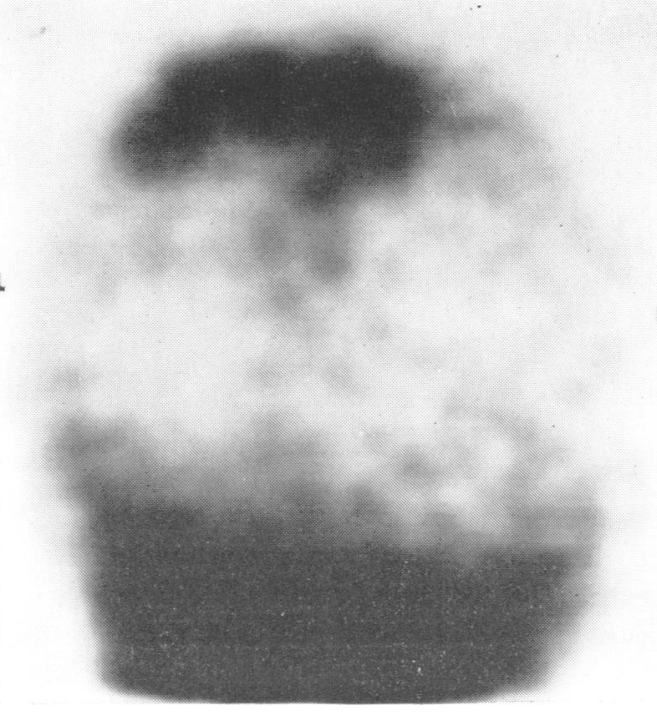

FIG. 9. Case 1. Isotope encephalogram (21 August 1970). Posterior scan showing dense area of abnormal uptake lying just below the rault and predominantly left-sided.

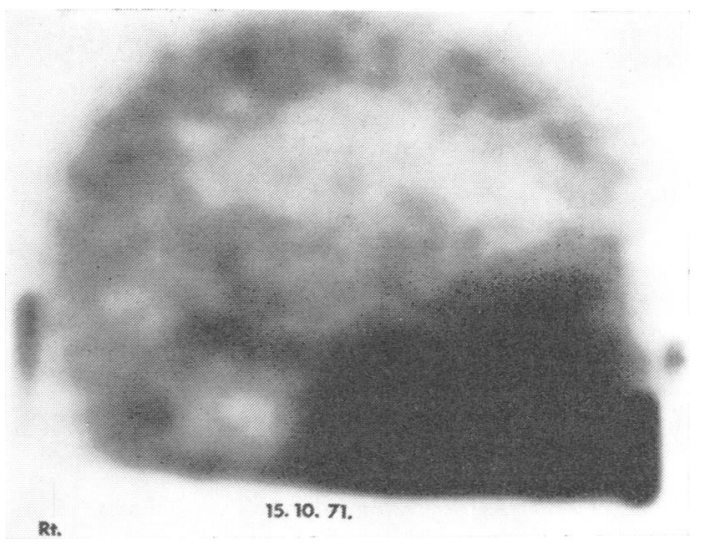

FIG. 11. Case 2. Isotope encephalogram (15 October 1971). Right lateral scan showing occipitotemporal lesion.

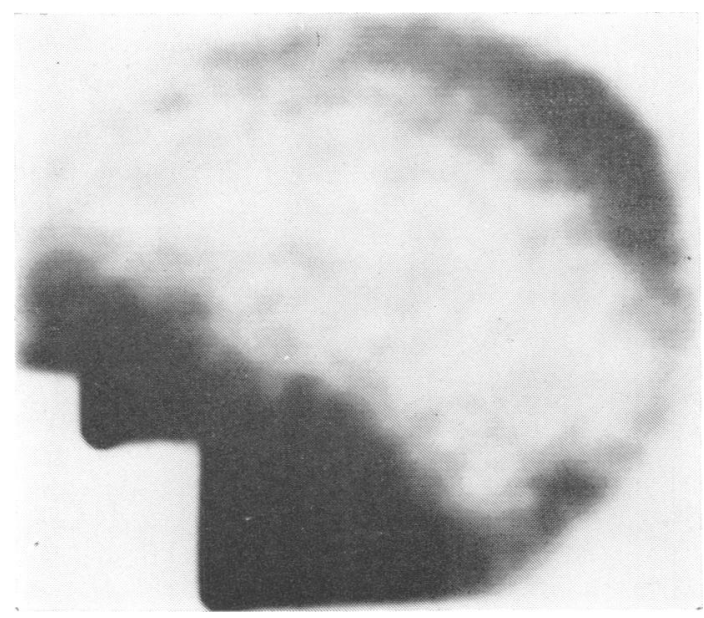

FIG. 10. Case 1. Isotope encephalogram (21 August 1970). Left lateral scan showing parietal lesion. Compare with Figs 4 and 7.
R*.

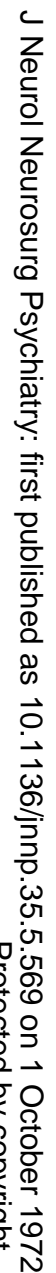
1971). Posterior scan showing increased uptake of right occipitotemporal lesion. 




FIG. 13. Case 2. Isotope encephalogram (2 November 1971). Right lateral scan showing diminished uptake of occipitotemporal lesion. Compare with Fig. 11.

port. Further improvement was delayed by sensory ataxia of his left side, affecting chiefly the hand and fingers. By 23 October he was able to identify objects in his left visual field but inattention hemianopia persisted. He was well enough to return home on 25 October. A third brain scan (Fig. 13) on 2 November



FIG. 14. Case 2. Isotope encephalogram (2 November 1971). Posterior scan showing improvement of right occipitotemporal lesion. Compare with Fig. 12.

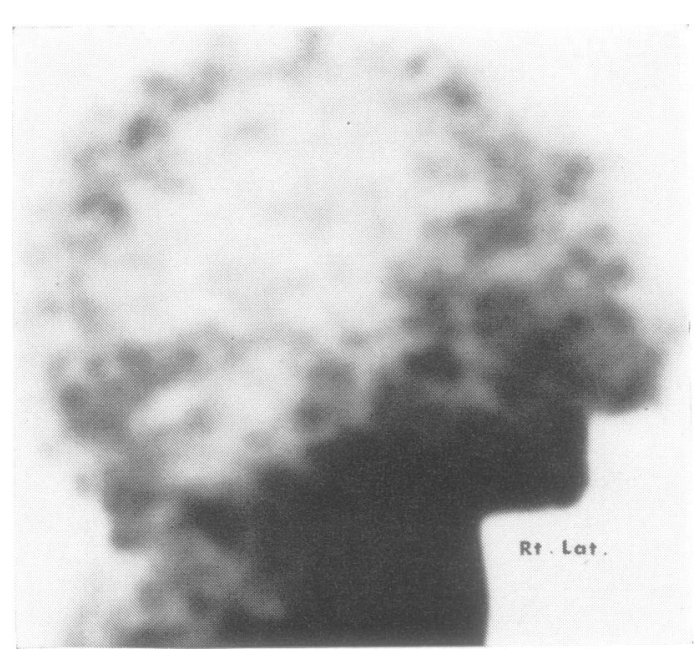

FIG. 15. Case 3. Isotope encephalogram (21 October $\overrightarrow{\vec{\omega}}$ 1968). Right lateral scan showing increased fronto- $\mathrm{D}$ temporal uptake.

showed that the right occipitotemporal lesion was ir still present, although the intensity of uptake wक्ष less. In the posterior scan (Fig. 14) the abnormal area 6 lay superficially. A month later he was well and wite out abnormal physical signs. The scan on 1 December $\vec{\theta}$ was normal.

In a previous case we had found that brat

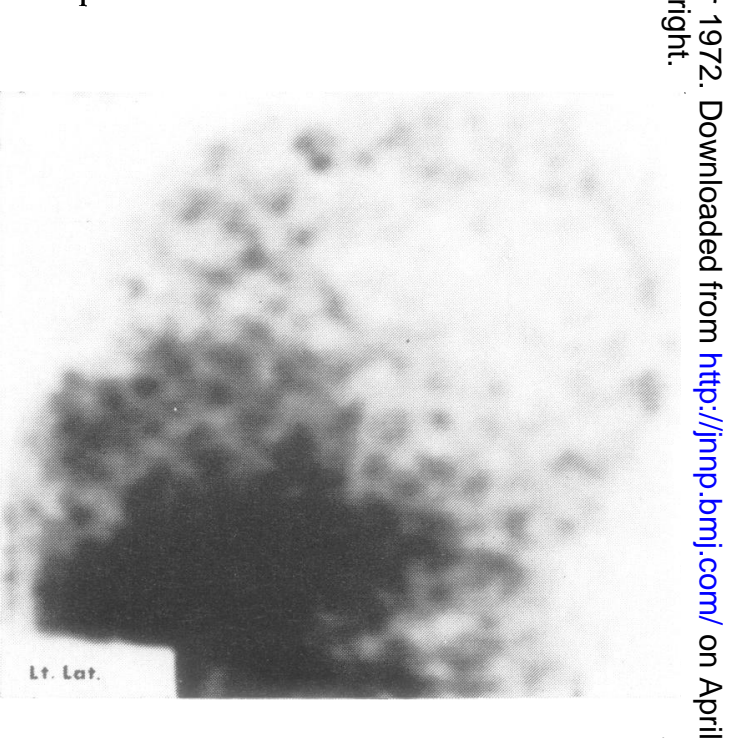

FIG. 16. Case 3. Isotope encephalogram (21 October 1968). Left lateral scan showing increased fronto-s temporal uptake. 
scanning could provide a vital diagnostic clue when a patient suspected of carcinomatous, or of spongiform, encephalopathy was found at necropsy to have necrotizing encephalitis.

\section{CASE 3}

A 63 year old woman had a three-month story of progressive loss of memory followed by unsteadiness, tremor, and drowsiness. She had lost much weight. On admission to hospital she was afebrile but later ran an irregular fever up to $38.5^{\circ} \mathrm{C}$, coinciding with clinical and radiological signs of pulmonary infection. General examination including the pelvis was otherwise normal.

Within days she became mute, earlier appearing confused and disoriented with almost total loss of recent memory and of retention and recall, and showing marked perseveration of both speech and action. She sat for long periods gazing vacantly about her, her attitude of repose frequently interrupted by myoclonic jerks. She was too apraxic to stand, even with help, and the static tremor of her arms became turbulent on movement. Pupils and

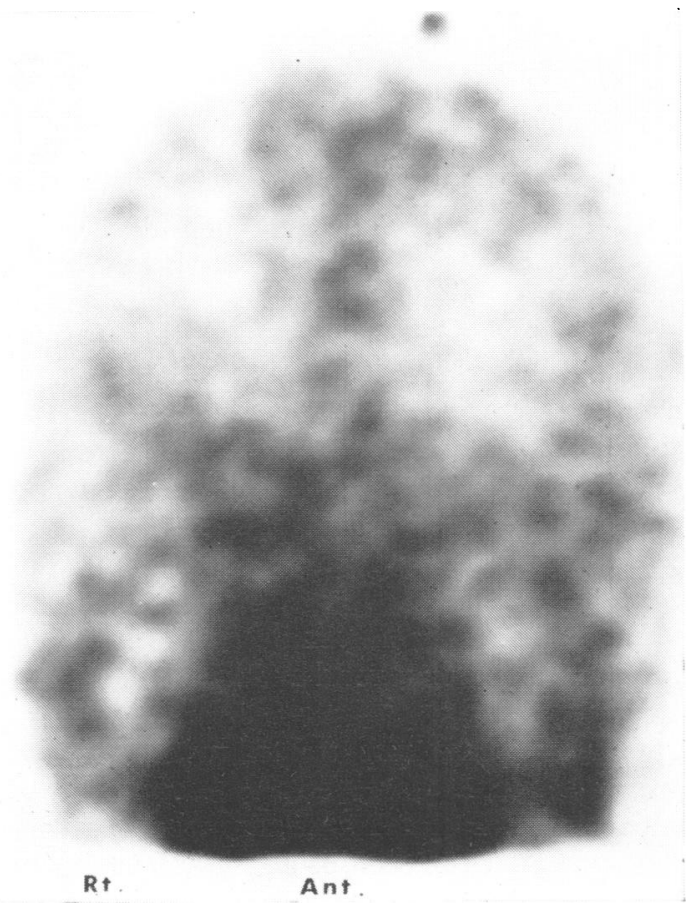

FIG. 17. Case 3. Isotope encephalogram (21 October 1968). Anterior scan showing increased bifrontal uptake. fundi were normal, the plantar responses flexor. Bilateral grasp and pouting reflexes were present.

Lumbar puncture showed a mild pleocytosis of 25 WBC/c.mm but on repetition the count was normal. Although the protein content was not raised, the Lange curve was 'paretic'. The EEG which was recorded twice was marred by artefact and showed a continuous background of low-voltage slow activity. An alpha rhythm at $9 \mathrm{~Hz}$ was distinguishable in parts of the first record. Paired sera for viral antibodies, reported shortly before her death, showed an initial titre to herpes simplex of $1 / 128$ falling after 24 days to $1 / 64$. Areas of increased uptake over the frontal lobes (Figs 15, 16, 17) were reported in the brain scan. Further investigation was abandoned because of her rapid deterioration.

At necropsy she was found to have a terminal bronchopneumonia and her right kidney had been destroyed by tuberculosis which was considered quiescent. No carcinoma was found. The brain showed changes of an acute encephalitis with necrosis and haemorrhage extending throughout the frontal and temporal lobes. The occipital lobes were less severely affected and the cerebellum and brainstem appeared macroscopically normal. Histological sections confirmed the gross appearance of necrotizing encephalitis but no inclusion bodies were found and culture of brain tissue obtained at necropsy was negative for viruses.

\section{DISCUSSION}

THE PATHOLOGICAL LESION A necrotizing encephalitis is the typical post-mortem finding in patients dying of herpesvirus infection of the brain (Haymaker, 1949; van Bogaert et al., 1955; Krücke, 1957; Haymaker et al., 1958; Brihaye, 1959; Jellinger et al., 1964; Adams and Jennett, 1967). Although the virus enters and destroys nerve-cells, astrocytes, and oligodendroglia (Wolf and Cowen, 1950; Ryden et al., 1965; Chou and Cherry, 1967; Bergouignan et al., $1968)$ its part in causing necrosis and haemorrhage is less clearly defined. Krücke (1957) recognized oedema, haemorrhage, and necrosis as separate stages of an evolving process. A viral vasculitis (Carmon et al., 1965; Hughes, 1969) is a further factor but it is not constantly present (Adams and Jennett, 1967).

Recovery from necrotizing encephalitis can occur (Dodge and Cure, 1956; Leider et al., 1965; Olson et al., 1967; Miller and Ross, 1968) but is much less likely than in cases of milder illness. Whereas the mortality rate for all cases of 
herpes encephalitis is under $50 \%$, nearly threequarters of those with necrotizing lesions die (Miller and Ross, 1968). In most recent reports of recovery an antiviral drug, idoxuridine, often combined with surgical decompression, has been given (Breeden et al., 1966; Marshall, 1967; Page et al., 1967; Bellanti, Guin, Grassi, and Olson, 1968; Nolan et al., 1970; Meyer et al., 1971; Rappel et al., 1971). Some evidence exists that milder cases of meningoencephalitis and of aseptic meningitis, which recover spontaneously, do not have necrotizing lesions (Miller and Ross, 1968), although the opportunity for pathological study is rare. They are clearly distinct from another group of cases, also without necrotizing lesions at necropsy, which have died of a fulminating infection before haemorrhage and necrosis have developed (Krücke, 1957; Bellanti et al., 1968).

POSITIVE AND NEGATIVE SCANS Positive brain scans occur only in cases of severe encephalitis and are not found in the majority of non-bacterial infections of the central nervous system (Davis and Taveras, 1966; Pedersen and Haase, 1970). Balfour et al. (1967) found that the abnormal pattern of uptake shown by their case of herpes encephalitis was unique in their experience of more than 4,000 brain scans. They contrasted a rounded zone, suggestive of an intratemporal mass, in the lateral scan with an elliptical area, curving under the vault, in the anterior and posterior scans. Their description resembles our own findings (Figs 1-14) and accords well with the illustrations of some isotope encephalograms which accompany recent case reports of herpes encephalitis (Halpern et al., 1970; Mishkin, 1970; Radcliffe et al., 1971).

Serial scanning of our first case showed that new lesions were emerging in the right hemisphere at a time of clinical remission (Figs 5 and 6) and anticipated by days focal epilepsy and other signs of relapsing infection. Such changes, however, should be viewed with caution as they may reflect no more than the physiopathology of repair, a similar progression being commonplace in the serial scans of infarction (Glasgow et al., 1965; Molinari et al., 1967; Usher and Quinn, 1969; Marshall and Popham, 1970). The increasing left occipitotemporal uptake of the third scan was wrongly interpreted as evidence of continuing infection and led to unnecessary therapy with idoxuridine. Similarly in our second case increasing density of uptake in the right occipitotemporal region (Figs 11 and 12) was seen after recovery had begun, subsequent scans showing resolution (Figs 13 and 15).

CHEMOTHERAPY The place of chemotherapy in herpes simplex infections of the nervous system was at first uncertain and its use was restricted to cases of suspected encephalitis from which her- $\overrightarrow{\bar{S}}$ pesvirus had been isolated. Early enthusiasm for $\overline{0}$ idoxuridine, chosen because of its success in treating herpetic keratitis (Leopold, 1965), was based on single case reports despite their authors' $\mathbb{\complement}$ caution over accepting such slender evidence is (Breeden et al., 1966; Buckley and MacCallum, $\vec{\circ}$ 1967; Evans, Gray, Miller, Jones, Weeks, and Wells, 1967; Marshall, 1967). Later experience, $\stackrel{\omega}{\sigma}$ however, confirmed the anti-viral action of the drug which was effective across the blood-brain barrier. Both mortality and long-term morbidity were reduced if idoxuridine was given promptly $r$ at the onset of encephalitis (Nolan et al., 1971 용 Meyer et al., 1971; Rappel et al., 1971).

Cytosine arabinoside was introduced by Jue $\stackrel{\circ}{2}$ Jensen (1970) for the treatment of generalized primary herpes and of severe herpes in patients with immunoparesis. One case of simian herpes్ virus encephalitis, a rare but lethal disorder, al recovered (Juel-Jensen, 1970). Its use in herpe simplex (Herpesvirus hominis) encephalitis has not previously been reported. Other forms of therapy which have been advocated are surgical decompression (Adams and Jennett, 1967), an interferon inducer (Bellanti, Catalano, and $\stackrel{\circ}{\mathcal{Q}}$ Chambers, 1971), and steroids (Upton, Barwick, $\stackrel{\varrho}{\rightrightarrows}$ and Foster, 1971) despite the theoretical dangers which include suppression of interferon (Longson and Beswick, 1971). Cytarabine has the advantage of being instantly available whereas idoxuridine needs careful and laborious preparation.

Our first case was treated with cytarabine, using a small dose, and subsequently with $\delta$ idoxuridine. Steroids and adrenocorticotrophin had been given before his admission to our unit. 음 The result was poor, the child remaining hemi- $\frac{D}{2}$ plegic, epileptic, and grossly retarded 18 months after the conclusion of therapy. A similar result $N_{\sigma}$ had been seen in the case previously reported $N$ 
from the unit (Evans et al., 1967) in which idoxuridine was started on the 56th day of illness. That patient is now resident in an institution for mentally retarded children, a severe epileptic with residual hemiplegia, and is liable to outbreaks of disturbed behaviour.

The second case was treated with cytarabine using a larger dose, similar to that for malignant disease, which was combined with dexamethasone as a means of reducing cerebral oedema. His response was prompt with a quick return to consciousness and early remission of hemiplegia and hemianopia. In the short follow-up period improvement has continued and all drugs, including anticonvulsants, have been withdrawn.

ELECTROENCEPHALOGRAPHY In his monograph on encephalitis and encephalopathy Radermecker (1956) described a typical sequence of EEG changes in acute necrotizing encephalitis. The generalized slow activity of diffuse brain disease was followed by marked flattening of the record in some leads, particularly those from the temporal areas, and by the emergence of epileptic and periodic complexes. An unusual feature was the apparent improvement of the EEG at the time of clinical deterioration.

Upton and Gumpert (1970), writing on the EEG diagnosis of herpes simplex encephalitis, found that periodic complexes, often focal over the temporal region, appeared during the first fortnight of the illness thereafter subsiding without parallel clinical improvement. The EEG recorded on the ninth day of illness and illustrated in their paper (Upton and Gumpert, 1970) is strikingly similar to that on the eighth day of our case 1 (Fig. 1) - a pattern of focal complexes arising from the left temporal region. Still present on the 12th day the periodic focal discharge had disappeared by the 18th day, although the brain scan on the 28th day (Figs 9 and 10) showed a persisting lesion of this area.

In cases of cerebral infarction delay in obtaining a positive scan has been attributed to oedema which obstructs the vessels at the margin of the lesion (Usher and Quinn, 1969). When the oedema subsides, after 10 to 14 days, the vessels dilate, capillaries proliferate, and abnormal quantities of isotope are concentrated in and around the infarct. In necrotizing encephalitis decay of electrical activity over an area of in- creased vascularity, as shown by the scan, may well indicate a region of almost total neuronal death. This may be the explanation for the series of events which were recorded clinically, electrically, and radiologically in the left posterior temporal region of our first case.

Dr. A. D. Evans provided the reports on virus serology and on virus isolation and culture, and Dr. B. H. Knight the account of the necropsy findings on case 3 .

\section{REFERENCES}

Adair, C. V., Gauld, R. L., and Smadel, J. E. (1953). Aseptic meningitis, a disease of diverse etiology: clinical and etiologic studies on 854 cases. Annals of Internal Medicine, 39, 675-704.

Adams, J. H., and Jennett, W. B. (1967). Acute necrotizing encephalitis: a problem in diagnosis. Journal of Neurology, Neurosurgery, and Psychiatry, 30, 248-260.

Afzelius-Alm, L. (1951). Aseptic (nonbacterial) encephalomeningitides in Gothenburg 1932-1950. Clinical and experimental investigation with special reference to the viruses of herpes, influenza, mumps and lymphocytic choriomeningitis. Acta Medica Scandinavica, 140, Suppl. 263, 1-98.

Balfour, H. H., Jr., Loken, M. K., and Blaw, M. E. (1967). Brain scan in a patient with herpes simplex encephalitis. Journal of Pediatrics, 71, 404-407.

Bellanti, J. A., Catalano, L. W., Jr., and Chambers, R. W. (1971). Herpes simplex encephalitis: virologic and serologic study of a patient treated with an interferon inducer. Journal of Pediatrics, 78, 136-145.

Bellanti, J. A., Guin, G. H., Grassi, R. M., and Olson, L. C. (1968). Herpes simplex encephalitis. Brain biopsy and treatment with 5-iodo-2'-deoxyuridine. Journal of Pediatrics, 72, 266-275.

Bennett, D. R., ZuRhein, G. M., and Roberts, T. S. (1962). Acute necrotizing encephalitis. A diagnostic problem in temporal lobe disease: report of three cases. Archives of Neurology, 6, 96-113.

Bergouignan, M., Julien, J., Vital, Cl., and Duvert, M. (1968). Notre expérience de l'encéphalite aiguë nécrosante. Mise en évidence du virus herpétique au microscope électronique. Presse Médicale, 76, 709-714.

Blackwood, W., Dudgeon, J. A., Newns, G. H., and Phillips, B. M. (1966). Case of encephalitis due to herpes simplex. British Medical Journal, 1, 1519-1521.

Bogaert, L. van, Radermecker, J., and Devos, J. (1955). Sur une observation mortelle d'encéphalite aiguë nécrosante. (Sa situation vis-à-vis du groupe des encéphalites transmises par arthropodes et de l'encéphalite herpétique.) Revue Neurologique, 92, 329-356.

Booth, C. B., Okazaki, H., and Gaulin, J. C. (1961). Acute inclusion encephalitis of herpes simplex type. Neurology (Minneap.), 11, 619-629.

Breeden, C. J., Hall, T. C., and Tyler, H. R. (1966). Herpes simplex encephalitis treated with systemic 5-iodo-2'deoxyuridine. Annals of Internal Medicine, 65, 1050-1056.

Brihaye, J. (1959). Étude des encéphalites herpétiques et des encéphalites nécrosantes aiguës. Acta Neurologica et Psychiatrica Belgica, 59, 1-114.

Buckley, T. F., and MacCallum, F. O. (1967). Herpes simplex virus encephalitis treated with idoxuridine. British Medical Journal, 2, 419-420. 
Carmon, A., Behar, A., and Beller, A. J. (1965). Acute necrotizing haemorrhagic encephalitis presenting clinically as a space-occupying lesion. A clinico-pathological study of six cases. Journal of Neurological Sciences, 2, 328-343.

Castleman, B. (Ed.) (1964). Case records of the Massachusetts General Hospital. Case 61-1964. New England Journal of Medicine, 271, 1313-1320.

Chou, S. M., and Cherry, J. D. (1967). Ultrastructure of Cowdry type $\mathbf{A}$ inclusions. I. In human herpes simplex encephalitis. Neurology (Minneap.), 17, 575-586.

Clizer, E. E., and Ioannides, G. (1971). Herpes simplex encephalitis. American Journal of Roentgenology, 112, 273275.

Cowdry, E. V. (1934). The problem of intranuclear inclusions in virus diseases. Archives of Pathology, 18, 527-542.

Davis, D. O., and Potchen, E. J. (1970). Brain scanning and intracranial inflammatory disease. Radiology, 95, 345-346.

Davis, D. O., and Taveras, J. M. (1967). Radiological aspects of inflammatory conditions affecting the central nervous system. Clinical Neurosurgery, 14, 192-210.

Delmas-Marsalet, P., Bergouignan, M., Castaing, R., Pasquier, P. du, and Vital, C. (1968). Fréquence actuelle des encéphalites herpétiques de l'adulte: sur une série personelle de huit cas confirmés par la microscopie électronique. Bulletin de l'Académie Nationale de Médecine, 152, 316-321.

Dodge, P. R., and Cure, C. W. (1956). Acute encephalitis with intranuclear cellular inclusions. A nonfatal case of probable herpetic etiology diagnosed by biopsy. New England Journal of Medicine, 255, 849-853.

Dowdle, W. R., Nahmias, A. J., Harwell, R. W., and Pauls, F. P. (1967). Association of antigenic type of Herpesvirus hominis with site of viral recovery. Journal of Immunology, 99, 974-980.

Drachman, D. A., and Adams, R. D. (1962). Herpes simplex and acute inclusion-body encephalitis. Archives of Neurology, 7, 45-63.

Duckett, S., Kelly, R., and Grant, H. C. (1963). Un cas de méningo-encéphalite nécrosante avec inclusions intracellulaires dû à une infection psittacosique possible. Revue Neurologique, 108, 899-902.

Evans, A. D., Gray, O. P., Miller, M. H., Jones, E. R. V., Weeks, R. D., and Wells, C. E. C. (1967). Herpes simplex encephalitis treated with intravenous idoxuridine. British Medical Journal, 2, 407-410.

Glasgow, J. L., Currier, R. D., Goodrich, J. K., and Tutor, F. T. (1965). Brain scans at varied intervals following C. V. A. Journal of Nuclear Medicine, 6, 902-916.

Halpern, S. E., Smith, C. W., Jr., and Ficken, V. (1970). ${ }^{98 \mathrm{~m}} \mathrm{Tc}$ brain scanning in herpes virus type I encephalitis. Journal of Nuclear Medicine, 11, 548-550.

Harland, W. A., Adams, J. H., and McSeveney, D. (1967). Herpes-simplex particles in acute necrotizing encephalitis. Lancet, 2, 581-582.

Harper, P. V., Beck, R., Charleston, D., and Lathrop, K. A. (1964). Optimization of scanning method using $\mathrm{Tc}^{99 \mathrm{~m}}$. Nucleonics, 22, No. 1, 50-54.

Haymaker, W. (1949). Herpes simplex encephalitis in man. With a report of three cases. Journal of Neuropathology and Experimental Neurology, 8, 132-154.

Haymaker, W., Smith, M. G., Bogaert, L. van, and de Chenar, C. (1958). Pathology of viral diseases in man characterized by nuclear inclusions. With emphasis on herpes simplex and subacute inclusion encephalitis. In Viral Encephalitis. Pp. 95-204. Edited by W. S. Fields and R. J. Blattner. Thomas: Springfield.

Heathfield, K. W. G., Pilsworth, R., Wall, B. J., and Corsellis, J. A. N. (1967). Coxsackie B5 infections in Essex, 1965, with particular reference to the nervous system. Quarterly Journal of Medicine, 36, 579-595.
Hunt, B. P., and Comer, E. O'B. (1955). Herpetic meningoencephalitis accompanying cutaneous herpes simplex. American Journal of Medicine, 19, 814-823.

Hughes, J. T. (1969). Pathology of herpes simplex encephalitis. In Virus Diseases and the Nervous System, pp. 29-37. Edited by C. W. M. Whitty, J. T. Hughes, and F. O. MacCallum. Blackwell: Oxford.

Itabashi, H. H., Bass, D. M., and McCulloch, J. R. (1966). Inclusion body of acute inclusion encephalitis. An electron- $\infty$ microscopic study in a case of suspected herpes simplex encephalitis. Archives of Neurology (Chic.), 14, 493-505.

Jacoby, G. A., Jr., Blennerhassett, J. B., and Richardson, E. P., Jr. (1971). Fulminant central-nervous-system disease with lowering of the cerebrospinal-fluid glucose. New England Journal of Medicine, 284, 1023-1031.

Jellinger, K., Poetsch, F., and Seitelberger, F. (1964). Akute nekrotisierende Einschlusskörperchen-Encephalitis. Isolierung von Herpes simplex-Virus aus dem Gehirn. Acta Neuropathologica, 3, 278-283.

Johnson, R. T. (1964). The pathogenesis of herpes virus encephalitis. I. Virus pathways to the nervous system of suckling mice demonstrated by fluorescent antibody ${ }^{\infty}$ staining. Journal of Experimental Medicine, 119, 343-356.

Johnson, R. T., Olson, L. C., and Buescher, E. L. (1968). Herpes simplex virus infections of nervous system. Problems in laboratory diagnosis. Archives of Neurology (Chic.), 18, 260-264.

Juel-Jensen, B. E. (1970). Severe generalized primary herpes treated with cytarabine. British Medical Journal, 2, 154-7 155.

Krücke, W. (1957). Über eine besondere Form der spontanen Encephalitis. Akute, subakute und chronisch-rezidivierende or Encephalitis mit Einschlusskörperchen. Nervenarzt, 28, 289-301.

Kuhl, D. E., Pitts, F. W., and Tucker, S. H. (1966). Bra岩 음 scanning of children using body section techniques am pertechnetate ${ }^{99 m}$ Tc. Acta Radiologica Diagnosis, 5, 8405854.

Leider, W., Magoffin, R. L., Lennette, E. H., and Leonar\&, L. N. R. (1965). Herpes-simplex-virus encephalitis. $\mathbb{R}$ possible association with reactivated latent infection. $N$ England Journal of Medicine, 273, 341-347.

Leopold, I. H. (1965). Clinical experience with nucleosides in herpes simplex eye infections in man and animals. Annals of the New York Academy of Sciences, 130, 181-191.

Longson, M., and Beswick, T. S. L. (1971). Dexamethasone treatment in herpes-simplex encephalitis. Lancet, 1, 749750.

MacCallum, F. O., Potter, J. M., and Edwards, D. H. (1964). 을 Early diagnosis of herpes-simplex encephalitis by brain $\varrho$ biopsy. Lancet, 2, 332-334.

McKee, A. P., Hudson, J. D., Kimura, J., and McCormick, W. F. (1968). Herpes simplex encephalitis. Southern Medical Journal, 61, 217-225.

Marshall, J., and Popham, M. G. (1970). Radioactive brain scanning in the management of cerebrovascular disease Journal of Neurology, Neurosurgery, and Psychiatry, 33, Э 201-204.

Marshall, W. J. S. (1967). Herpes simplex encephalitis treated with idoxuridine and external decompression. Lancet, 2, 579-580.

Maynard, C. D., and Kelsey, W. M. (1969). Brain scanning in the pediatric age group. Developmental Medicine and Child Neurology, 11, 69-76.

Meyer, H. M., Jr., Johnson, R. T., Crawford, I. P., Dascomb, H. E., and Rogers, N. G. (1960). Central nervous system syndromes of 'viral' etiology. A study of 713 cases. American Journal of Medicine, 29, 334-347.

Meyer, J. S., Bauer, R. B., Rivera-Olmos, V. M., Nolan, D. C., and Lerner. A. M. (1970). Herpesvirus hominis N 
encephalitis. Neurological manifestations and use of idoxuridine. Archives of Neurology, 23, 438-450.

Miller, J. D., and Ross, C. A. C. (1968). Encephalitis. A fouryear survey. Lancet, 1, 1121-1126.

Miller, J. K., Hesser, F., and Tompkins, V. N. (1966). Herpes simplex encephalitis. Report of 20 cases. Annals of Internal Medicine, 64, 92-103.

Mishkin, F. S. (1970). Radionuclide angiogram and scan findings in a case of herpes simplex encephalitis. Journal of Nuclear Medicine, 11, 608-609.

Molinari, G. F., Pircher, F., and Heyman, A. (1967). Serial brain scanning using technetium ${ }^{99 \mathrm{~m}}$ in patients with cerebral infarction. Neurology (Minneap.), 17, 627-636.

Nahmias, A. J., Dowdle, W. R., Josey, W. E., Naib, Z. M., Painter, L. M., and Luce, C. (1969). Newborn infection with herpesvirus hominis types 1 and 2. Journal of Pediatrics, 75, 1194-1203.

Nolan, D. C., Carruthers, M. M., and Lerner, A. M. (1970). Herpesvirus hominis encephalitis in Michigan. Report of thirteen cases, including six treated with idoxuridine. New England Journal of Medicine, 282, 10-13.

Olson, L. C., Buescher, E. L., Artenstein, M. S., and Parkman, P. D. (1967). Herpesvirus infections of human central nervous system. New England Journal of Medicine, 277, 12711277.

Page, L. K., Tyler, H. R., and Shillito, J., Jr. (1967). Neurosurgical experiences with herpes simplex encephalitis. Journal of Neurosurgery, 27, 346-352.

Pedersen, M., and Haase, J. (1970). Scintillation camera and rectilinear scanner for detection of space-occupying intracranial lesions. Acta Radiologica. Diagnosis, 10, 534-544.

Pierce, N. F., Portnoy, B., Leeds, N. E., Morrison, R. L., and Wehrle, P. F. (1964). Encephalitis associated with herpes simplex infection presenting as a temporal-lobe mass. Report of 2 cases with survival. Neurology (Minneap.), 14, 708-713.

Radcliffe, W. B., Guinto, F. C., Jr., Adcock, D. F., and Krigman, M. R. (1971). Herpes simplex encephalitis. A radiologic-pathologic study of 4 cases. American Journal of Roentgenology, 112, 263-272.

Radermecker, J. (1956). Encéphalites à prédominance corticobasale (temporo-hippocampique) virales à tendance nécrosante. In Systématique et Electroencéphalographie de Encéphalites et Encéphalopathies. Electroencephalography and Clinical Neurophysiology, Suppl. 5, 106-117.
Rappel, M., Dubois-Dalcq, M., Sprecher, S., Thiry, L., Lowenthal, A., Pelc, S., and Thys, J. P. (1971). Diagnosis and treatment of herpes encephalitis. A multidisciplinary approach. Journal of the Neurological Sciences, 12, 443-458.

Rawls, W. E., Dyck, P. J., Klass, D. W., Green, H. D. III, and Herrmann, E. C. Jr. (1966). Encephalitis associated with herpes simplex virus. Annals of Internal Medicine, 64, 104-115.

Ross, C. A. C., and Stevenson, J. (1961). Herpes-simplex meningoencephalitis. Lancet, 2, 682-685.

Ryden, F. W., Moses, H. L., Ganote, C. E., and Beaver, D. L. (1965). Herpetic (inclusion-body) encephalitis. Southern Medical Journal, 58, 903-913.

Scheid, W., Jochheim, K.-A., and Stammler, A. (1955). Tödlicher Verlauf einer Infektion mit dem Virus der lymphocytären Choriomeningitis. Deutsche Zeitschrift für Nervenheilkunde, 174, 123-139.

Smith, E. M. (1965). Internal dose calculation for ${ }^{99 \mathrm{~m}} \mathrm{Tc}$. Journal of Nuclear Medicine, 6, 231-251.

Smith, M. G., Lennette, E. H., and Reames, H. R. (1941). Isolation of the virus of herpes simplex and the demonstration of intranuclear inclusions in a case of acute encephalitis. American Journal of Pathology, 17, 55-68.

Sweet, W. H., Mealey, J., Jr., Aronow, S., and Brownell, G. L. (1961). Localization of focal intracranial lesions by scanning of rays from positron-emitting isotopes. Clinical Neurosurgery, 7, 159-199.

Upton, A. R. M., Barwick, D. D., and Foster, J. B. (1971). Dexamethasone treatment in herpes-simplex encephalitis. Lancet, 1, 290-291.

Upton, A., and Gumpert, J. (1970). Electroencephalography in diagnosis of herpes-simplex encephalitis. Lancet, 1, 650652.

Usher, M. S., and Quinn, J. L., III. (1969). Serial brain scanning with Technetium ${ }^{99 m}$ pertechnetate in cerebral infarction. American Journal of Roentgenology, 105, 728-733.

Wolf, A., and Cowen, D. (1950). Herpes simplex encephalitis. Transactions of the American Neurological Association, 75, 65-68.

Zuelzer, W. W., and Stulberg, C. S. (1952). Herpes simplex virus as the cause of fulminating visceral disease and hepatitis in infancy. Report of eight cases and isolation of the virus in one case. American Journal of Diseases in Childhood, 83, 421-439. 